\title{
Fuzzy Logic Menganalisis Pengaruh Media Sosial Terhadap Perilaku Masyarakat Adat Kenagarian Kinari
}

\author{
Irzal Arief Wisky ${ }^{\mathrm{a}}$, Dhio Saputra ${ }^{\mathrm{b}}$ \\ ${ }^{a}$ Sistem Informasi, Fakultas Ilmu Komputer, Universitas Putra Indonesia "YPTK" Padang, irzal.arief12@ gmail.com \\ bistem Informasi, Fakultas Ilmu Komputer, Universitas Putra Indonesia "YPTK” Padang, dhiosaputra.mkom@gmail.com
}

\begin{abstract}
The purpose of this study was to build a Fuzzy Logic application to analyze the influence of social media on the behavior of the Kenagarian Kinari indigenous people. This research uses Fuzzy Logic Resistant model because in this method there is a variable in the form of frequency variables and activity variables on a fuzzy model, where later these variables can produce a fuzzy set as a benchmark, the higher the results of the fuzzy set obtained, the higher the effect on us, where the results are displayed in the form of community conditions related to the use of social media. The results of this study are also equipped with fuzzy membership degree representation and fuzzy processing conclusions that are displayed on information system applications using Visual Basic programming language, thus helping system users to analyze the influence of social media based on fuzzy variables, as well as the existence of Fuzzy Logic applications. social media influence on people's behavior. This system is capable of storing fuzzy set representations with $85 \%$ accuracy.
\end{abstract}

Keywords: fuzzy logic, social media, fuzzy set, indigenous people

\begin{abstract}
Abstrak
Tujuan dari penelitian ini adalah untuk membangun aplikasi Fuzzy Logic untuk menganalisa pengaruh media sosial terhadap perilaku Masyarakat adat Kenagarian Kinari. Penelitian ini menggunakan metode Fuzzy Logic model Tahani karena dalam metode ini terdapat suatu variabel berupa variabel frekuensi dan variabel aktivitas pada suatu model fuzzy, dimana nantinya variabel tersebut dapat menghasilkan Himpunan Fuzzy sebagai tolak ukur, semakin tinggi hasil Himpunan Fuzzy yang diperoleh maka semakin tinggi pengaruhnya terhadap kita, dimana hasilnya ditampilkan dalam bentuk kondisi Masyarakat yang terkait dengan penggunaan media sosial. Hasil penelitian ini juga dilengkapi dengan representasi derajat keanggotaan Fuzzy dan kesimpulan pemrosesan Fuzzy yang ditampilkan pada aplikasi sistem informasi menggunakan bahasa pemrograman Visual Basic, sehingga membantu pengguna sistem dalam menganalisa pengaruh media sosial berdasarkan variabel fuzzy, serta dengan adanya aplikasi Fuzzy Logic ini diperoleh hasil seberapa besar pengaruh media sosial terhadap perilaku masyarakat. Sistem ini mampu menyimpan representasi himpunan fuzzy dengan keakuratan $85 \%$.
\end{abstract}

Kata kunci: fuzzy logic, media sosial, himpunan fuzzy, masyarakat adat

(C) 2018Jurnal RESTI

\section{Pendahuluan}

Pada era teknologi sekarang ini setiap orang memiliki akun media sosial, seperti: WhatsApp, Facebook, Twitter, Path, Instagram, dan lain sebagainya. Kondisi ini seperti sebuah kelaziman yang mengubah cara berkomunikasi pada era serba digital seperti sekarang, Jika dahulu, perkenalan dilakukan dengan cara konvensional, yakni dengan saling tukar kartu nama, sekarang setiap kita bertemu orang yang baru dikenal cenderung untuk bertukar alamat akun atau pertemanan di media sosial [1].

Perubahan yang terjadi di bidang teknologi informasi maupun inovasi internet menyebabkan tidak hanya memunculkan media tekonologi yang baru saja, tetapi juga mempengaruhi kehidupan manusia, seperti komunikasi maupun interaksi, juga mengalami perubahan yang sebelumnya tidak pernah diduga. Dunia seolah-olah tidak memiliki batasan dan tidak ada kerahasiaan yang bisa ditutupi, kita dapat mengetahui aktivitas orang lain melalui media sosial, sementara kita tidak kenal dan tidak pernah bertemu tatap muka atau berada di luar jaringan dengan orang tersebut, hal tersebut merupakan sebuah tantangan sekaligus kenyataan yang tidak dapat dipungkiri, dengan kehadiran media sosial dan semakin berkembangnya jumlah pengguna dari hari ke hari memberikan fakta menarik betapa kekuatan internet bagi kehidupan [2].

Diterima Redaksi : 12-09-2018 | Selesai Revisi : 16-09-2018 | Diterbitkan Online : 12-12-2018 
Logika fuzzy berasal dari himpunan fuzzy. Berbeda anggotanya memiliki derajat keanggotaan yang bernilai dengan himpunan tegas, dimana suatu objek dapat kontinu antara 0 sampai 1. Sejak ditemukan pertama menjadi anggota atau bukan anggota, himpunan fuzzy kali oleh Lotfi A. Zadeh pada tahun 1965, logika fuzzy adalah himpunan yang keanggotaan objek-objeknya telah digunakan pada lingkup domain permasalahan hanya sebagian[3].

Logika fuzzy diyakini sangat fleksibel dan memiliki toleransi terhadap data-data yang ada. Dengan yang cukup luas, seperti kendali proses, klasifikasi dan pencocokan pola, manajemen dan pengambilan keputusan dan lain-lain [7].

menggunakan logika fuzzy, akan dihasilkan suatu Secara umum, fuzzy logic adalah sebuah metodologi model dari suatu sistem yang mampu membantu "berhitung" dengan variabel kata-kata (linguistic menganalisa pengaruh media sosial terhadap perilaku variable), sebagai pengganti berhitung dengan masyarakat adat Kenagarian Kinari.

Dengan demikian kehadiran media sosial menjadi fenomenal. WhatsApp, Facebook, Twitter, Path hingga Instagram adalah beberapa ragam media sosial yang Logika fuzzy adalah cara yang tepat / mudah untuk diminati oleh banyak masyarakat. Oleh karena itu, memetakan input-output didasari oleh konsep melalui tulisan ini, penulis ingin membahas Fuzzy himpunan fuzzy, dapat kita lihat pada gambar 1.

Logic Menganalisa Pengaruh Media Sosial Terhadap Perilaku Masyarakat Adat Kenagarian Kinari.

\section{Tinjauan Pustaka}

\subsection{Definisi Media Sosial}

Istilah media sosial tersusun dari dua kata, yakni "media" dan "sosial". "media" diartikan sebagai alat komunikasi [4]. Sedangkan kata "sosial" diartikan sebagai kenyataan sosial bahwa setiap individu melakukan aksi yang memberikan kontribusi kepada masysrakat. Pernyataan ini menegaskan bahwa pada kenyataannya, media dan semua perangkat lunak merupakan "sosial" atau dalam makna bahwa keduanya merupakan produk dari proses sosial [5].

Dari pengertian masing-masing kata tersebut, maka dapat disimpulkan bahwa media sosial adalah alat komunikasi yang digunakan oleh pengguna dalam proses sosial [2].

\subsection{Sistem Pendukung Keputusan}

Pengambilan keputusan adalah suatu proses memilih diantara berbagai alternatif, pengambilan keputusan manajerial sinonim dengan proses keseluruhan dari manajemen. Sistem pendukung keputusan dapat didefinisikan sebagai sebuah sistem yang dimaksudkan Database adalah suatu koleksi data yang saling untuk mendukung para pengambil keputusan berhubungan secara logis dan menggambarkan manajerial dalam situasi keputusan tidak integrasi antara suatu tabel dengan tabel lainnya, yang terstruktur. SPK dimaksudkan untuk menjadi alat dirancang untuk memenuhi kebutuhan informasi dari bantu bagi para pengambil keputusan untuk suatu organisasi [10]. memperluas kapabilitas mereka, namun tidak untuk menggantikan penilaian mereka. Selain itu juga sistem pendukung keputusan ditujukan untuk keputusan-keputusan yang memerlukan penilaian atau pada keputusan-keputusan yang sama sekali tidak dapat didukung oleh algoritma [6].

\subsection{Fuzzy Logic}

Logika fuzzy (fuzzy logic) adalah salah satu cabang dari

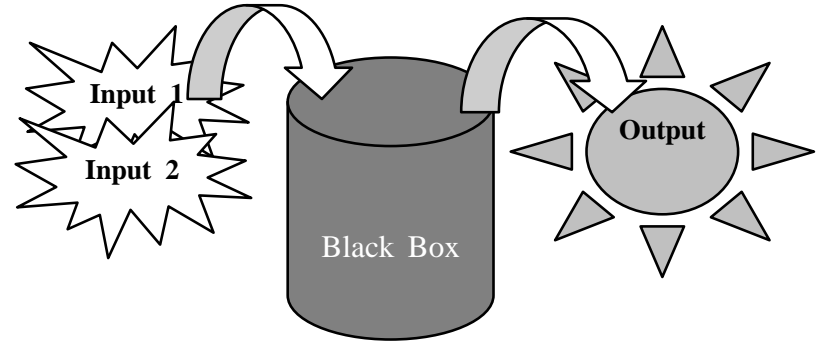

Gambar 1 Pemetaan Input - Output

Di antara input dan output terdapat black box. Di dalam black box terdapat proses yang tidak diketahui, bisa didekati dengan pendekatan sistem linear, ekonomi, interpolasi, sistem pakar atau logika fuzzy. Namun, seperti yang diungkapkan Lotfi Zadeh: "Dalam hampir setiap kasus, cara fuzzy lebih cepat dan lebih murah".

\subsection{Fuzzy Database}

Sistem basis data (database system) adalah suatu sistem informasi yang mengintegrasikan kumpulan data yang saling berhubungan satu dengan yang lainnya dan membuatnya tersedia untuk beberapa aplikasi dalam suatu organisasi [9].

Fuzzyfikasi Query diasumsikan sebuah query konvensional (nonfuzzy), DBMS yang akan mencoba membuat dan menerapkan sebuah sistem dasar logika fuzzy query (fuzzy logic based querying system). Kelebihan query fuzzyfikasi yaitu dapat mencapai kelenturan (flexibility) dari DBMS, penanganan error otomatis, pencarian yang fleksibel, dan kesanggupan merespon kosong.

AI (artificial intelligence). Logika fuzzy merupakan Konsep dari sebuah relasi fuzzy dalam sebuah DBMS modifikasi dari teori himpunan dimana setiap menggunakan derajat keanggotaan $(\mu)$ yang 
didefinisikan pada kumpulan domain $X=\{X 1, \ldots X n\}$, Model Fuzzy

dan telah di-generate pada relasi luar oleh nilai tengah Pada proses ini terdapat 2 variabel dan 1 fungsi output, fuzzy). Sintaks query yang di gunakan adalah sebagai yakni berupa variabel frekuensi dan variabel aktivitas berikut : serta fungsi output berupa kesimpulan.

select $<\mathrm{n}$ or $\mathrm{t}><$ attributes $>$ from $<$ relation $>$

Where < fuzzy condition>
Fungsi Keanggotaan

Pada proses ini dilakukan proses perhitungan dengan Awal penanganan ketidakpastian dengan manajemen menggunakan himpunan fuzzy terhadap masing-masing basis data dikembangkan di dalam kerangka variabel.

manajemen sistem basis data yang bukan fuzzy. Biasanya, sistem ini berhadapan dengan evaluasi dan Pembuatan Rule

konstruksi tentang fuzzy query dengan database yang Pada tahapan ini terdapat beberapa langkah yang bersifat tegas, dan mengabaikan permasalahan dalam dikerjakan untuk melalukan pengolahan data melalui penyajian langsung dari data fuzzy di DBMS [11].

Sebagian besar basis data fuzzy merupakan perluasan dari model basis data relasional, namun dikemas dalam formulasi yang berbeda tergantung pada tipe ambiguitas yang akan diekspresikan dan dimanipulasi. Tahani mendeskripsikan suatu metode untuk melakukan pengolahan query fuzzy didasarkan pada manipulasi data. Disini konsep teori fuzzy lebih banyak digunakan untuk melakukan pengolahan query. Basis data yang diusulkan oleh Zadeh, mengekspresikan ambiguitas data dengan cara memperluas model data. Perluasan dilakukan dengan cara menggunakan relasi fuzzy berupa grade yang ditambahkan pada relasi standar [9].

\subsection{Fuzzy Database Model Tahani}

Fuzzy Tahani adalah salah satu cabang dari logika fuzzy, yang merupakan salah satu metode fuzzy yang menggunakan basis data standar. Tahani mendeskripsikan suatu metode pemrosesan query fuzzy, dengan didasarkan atas manipulasi bahasa yang dikenal dengan nama SQL (Structured Query Language), sehingga model fuzzy Tahani sangat tepat digunakan dalam proses pencarian data yang tepat dan akurat[8].

\section{Metodologi Penelitian}

Urutan proses dari penelitian ini dapat dilihat pada Gambar 2. Dimana setiap bagian diuraikan setelah gambar 2.

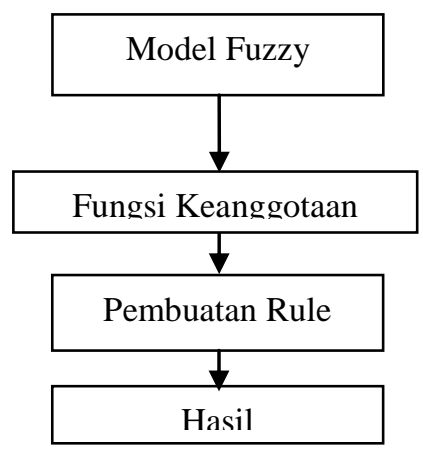

Gambar 2 Tahapan Proses Penelitian sebuah rule atau aturan yang dibuat, sehinga analisis data sampai dengan mendapatkan hasil mendapatkan kesimpulan yang sebenarnya.

Hasil

Setelah dilakukan pengolahan data Fuzzy, maka pada tahapan ini akan diambil kesimpulan yaitu pengaruh media sosial terhadap perilaku masyarakat.

\section{Hasil dan Pembahasan}

\subsection{Analisa Data}

Pada dasarnya kegiatan yang dilakukan pada tahap analisis ini ada dua bagian, yaitu tahap survey pengumpulan data dan analisis terstruktur yang secara garis besar untuk memperoleh pengertian dari permasalahan-permasalahan dan pertimbanganpertimbangan yang mengarah ke pengembangan sistem. Memperkirakan kendala-kendala yang akan dihadapi dalam pengembangan sistem tersebut dan menemukan suatu pendukung keputusan.

Analisis dan perancangan bertujuan untuk membentuk optimasi dari aplikasi yang akan kita bangun dengan mempertimbangkan faktor-faktor permasalahan kebutuhan yang ada dalam sistem. Upaya yang dapat dilakukan adalah dengan mencari kombinasi perangkat lunak dan teknologi yang tepat sehingga dapat menghasilkan hasil yang tepat dan mudah diimplementasikan.

\subsection{Model Fuzzy}

Masalah yang dibahas dalam penelitian ini adalah mengenai pengaruh media sosial. Setelah melakukan wawancara dengan tokoh masyarakat, sehingga mendapatkan kejelasan tentang variabel tersebut. Beberapa variabel pada pengaruh media sosial yang dibahas dalam penelitian ini terlihat pada Gambar 3.

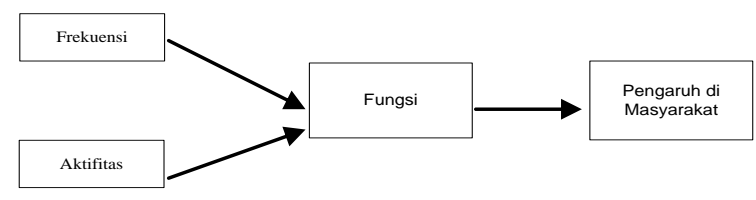

Gambar 3. Model Fuzzy 


\section{Fungsi Keanggotaan}

Setiap variabel fuzzy menggunakan fungsi keanggotaan bahu dan segitiga sebagai pendekatan untuk memperoleh derajat keanggotaan suatu nilai dalam suatu himpunan fuzzy.

Fungsi Keanggotaan Frekuensi

Untuk variabel frekuensi dikategorikan dalam himpunan fuzzy tidak sering, sering dan sering sekali. 4.2.1 Fungsi Keanggotaan Aktifitas

Untuk himpunan fuzzy tidak sering dan sering sekali menggunakan pendekatan fungsi keanggotaan yang berbentuk bahu sedangkan untuk himpunan sering menggunakan pendekatan fungsi keanggotaan yang berbentuk segitiga, seperti yang terlihat pada gambar 4 .

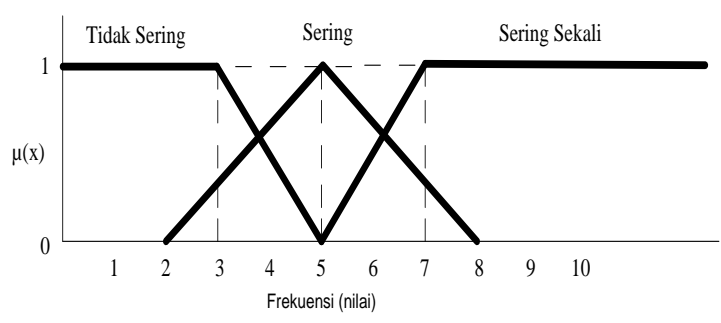

Gambar 4. Fungsi Keanggotaan Untuk Frekuensi

Himpunan fuzzy tidak Sering memiliki domain [0, 0, 2, 5], dengan derajat keanggotaan tertingginya (=1) terletak pada nilai 0 - 5. Himpunan fuzzy tidak sering direpesentasikan dengan fungsi keanggotaan berbentuk bahu, seperti terlihat pada persamaan 1 .

$\mu$ Tidak Sering $[\mathrm{X}] \quad= \begin{cases}1 ; & x \leq 2 \\ \frac{5-\mathrm{x}}{5-2} ; & \leq x \leq 5 \\ 0 ; & x \geq 5\end{cases}$

Himpunan fuzzy sering memiliki domain [2, 5, 8] dengan derajat keanggotaan tertingginya $(=1)$ terletak pada nilai 5. Himpunan fuzzy sering direpesentasikan dengan fungsi keanggotaan berbentuk segitiga, seperti terlihat pada persamaan 2 .

$$
\mu \operatorname{Sering}[x]= \begin{cases}0 ; & \mathrm{x} \leq 2 \text { atau } \mathrm{x} \geq 8 \\ \frac{\mathrm{X}-2}{5-2} & ; 2 \leq x \leq 5 \\ \frac{8-\mathrm{x}}{8-5} & ; 5 \leq x \leq 8\end{cases}
$$

Himpunan fuzzy sering sekali akan memiliki domain [5, $8,9,10]$ dengan derajat keanggotaannya tertingginya (=1) terletak pada nilai 10. Himpunan fuzzy sering sekali direpesentasikan dengan fungsi keanggotaan berbentuk bahu, seperti terlihat pada persamaan 3 . $\mu$ Sering Sekali[x] $= \begin{cases}0 ; & x \leq 5 \\ \frac{\mathrm{X}-5}{10-5} & ; 5 \leq x \leq 10 \\ 1 ; & x \geq 10\end{cases}$

Untuk variabel aktifitas dikategorikan dalam himpunan fuzzy tidak sering, sering, sering sekali. Untuk himpunan fuzzy tidak sering dan sering sekali menggunakan pendekatan fungsi keanggotaan yang berbentuk bahu sedangkan untuk himpunan sering menggunakan pendekatan fungsi keanggotaan yang berbentuk segitiga, seperti yang terlihat pada gambar 5 .

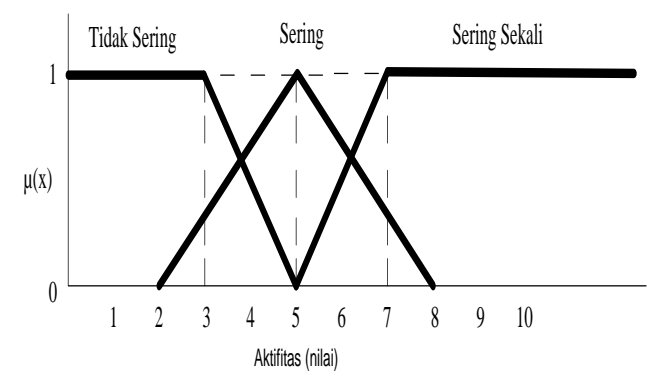

Gambar 5. Fungsi Keanggotaan Untuk Variabel Aktifitas

Untuk variabel penghasilan dibagi menjadi 3 himpunan fuzzy, yaitu tidak sering, sering dan sering

Himpunan fuzzy tidak Sering memiliki domain [0, 0, 2, 5], dengan derajat keanggotaan tertingginya (=1) terletak pada nilai 0 - 5. Himpunan fuzzy tidak sering direpesentasikan dengan fungsi keanggotaan berbentuk bahu, seperti terlihat pada persamaan 4 .

$\mu$ Tidak Sering $[\mathrm{X}]= \begin{cases}1 ; & x \leq 2 \\ \frac{5-\mathrm{X}}{5-2} & 2 \leq x \leq 5 \\ 0 ; & x \geq 5\end{cases}$

Himpunan fuzzy sering memiliki domain [2, 5, 8] dengan derajat keanggotaan tertingginya $(=1)$ terletak pada nilai 5. Himpunan fuzzy sering direpesentasikan dengan fungsi keanggotaan berbentuk segitiga, seperti terlihat pada persamaan 5 . 


$$
\mu \operatorname{Sering}[x]= \begin{cases}0 ; & x \leq 2 \text { atau } x \geq 8 \\ \frac{X-2}{5-2} & ; 2 \leq x \leq 5 \\ \frac{8-x}{8-5} & ; 5 \leq x \leq 8\end{cases}
$$

$\mu$ Berpengaruh $[x]$

$$
= \begin{cases}0 ; & \mathrm{x} \leq 2 \text { atau } \mathrm{x} \geq 8 \\ \frac{\mathrm{X}-2}{5-2} & ; 2 \leq x \leq 5 \\ \frac{8-\mathrm{x}}{8-5} & ; 5 \leq x \leq 8\end{cases}
$$

Himpunan fuzzy sering sekali akan memiliki domain [5, Himpunan fuzzy Sangat berpengaruh akan memiliki $8,9,10]$ dengan derajat keanggotaannya tertingginya domain $[5,8,9,10]$ dengan derajat keanggotaannya $(=1)$ terletak pada nilai 10. Himpunan fuzzy sering tertingginya $(=1)$ terletak pada nilai 10. Himpunan sekali direpesentasikan dengan fungsi keanggotaan fuzzy sangat berpengaruh direpesentasikan dengan berbentuk bahu, seperti terlihat pada persamaan 6 .

$$
\mu \text { Sering Sekali }[x]= \begin{cases}0 ; & x \leq 5 \\ \frac{\mathrm{X}-5}{10-5} & ; 5 \leq x \leq 10 \\ 1 ; & x \geq 10\end{cases}
$$

\subsubsection{Fungsi Keanggotaan Tentang Output}

Fungsi keanggotaan untuk keterangan Pengaruh di Masyarakat mempunyai 3 buah himpunan fuzzy yaitu Tidak Berpengaruh, Berpengaruh dan Sangat Berpengaruh dengan menggunakan pendekatan fungsi keanggotaan yang berbentuk bahu, seperti yang terlihat pada gambar 6 .

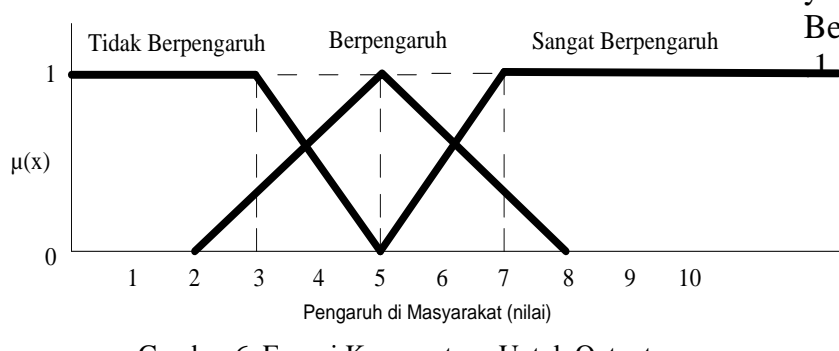

Gambar 6. Fungsi Keanggotaan Untuk Output

Himpunan fuzzy tidak berpengaruh memiliki domain $[0,0,2,5]$, dengan derajat keanggotaan tertingginya (=1) terletak pada nilai 0 - 5. Himpunan fuzzy tidak berpengaruh direpesentasikan dengan fungsi keanggotaan berbentuk bahu, seperti terlihat pada persamaan 7 .

$$
\mu \text { Tidak Berpengaruh }[\mathrm{X}]= \begin{cases}1 ; & x \leq 2 \\ \frac{5-\mathrm{X}}{5-2} & ; \leq x \leq 5 \\ 0 ; & x \geq 5\end{cases}
$$
fungsi keanggotaan berbentuk bahu, seperti terlihat pada persamaan 9 .

$\mu$ Sangat Berpengaruh $[\mathrm{x}]= \begin{cases}0 ; & x \leq 5 \\ \frac{\mathrm{X}-5}{10-5} & ; 5 \leq x \leq 10 \\ 1 ; & x \geq 10\end{cases}$

\subsection{Pembuatan Rule}

Pembuatan rule adalah menetapkan rule-rule yang berguna untuk menganalisis pengaruh media social di masyarakat. Pembuatan rule ini didasarkan pada kasus yang terjadi di lapangan, dengan rule yang baik. Berikut adalah rule-rulenya, seperti terlihat pada tabel

Tabel 1. Rule-Rule

\begin{tabular}{ll}
\hline No & \multicolumn{1}{c}{ Rule } \\
\hline$[R 1]$ & $\begin{array}{l}\text { If (frekuensi is tidak sering) and (aktifitas is tidak } \\
\text { sering) then (keputusan is tidak berpengaruh) }\end{array}$ \\
{$[\mathrm{R} 2]$} & $\begin{array}{l}\text { If (frekuensi is sering) and (aktifitas is tidak sering) } \\
\text { then (keputusan is tidak berpengaruh) }\end{array}$ \\
{$[\mathrm{R} 3]$} & $\begin{array}{l}\text { If (frekuensi is sering sekali) and (aktifitas is sering) } \\
\text { then (keputusan is sangat berpengaruh) }\end{array}$ \\
{$[\mathrm{R} 4]$} & $\begin{array}{l}\text { If (frekuensi is tidak sering) and (aktifitas is sering) } \\
\text { then (keputusan is tidak berpengaruh) }\end{array}$ \\
{$[\mathrm{R} 5]$} & $\begin{array}{l}\text { If (frekuensi is sering) and (aktifitas is sering sekali) } \\
\text { then (keputusan is sangat berpengaruh) }\end{array}$ \\
{$[\mathrm{R} 6]$} & $\begin{array}{l}\text { If (frekuensi is sering sekali) and (aktifitas is tidak } \\
\text { sering) then (keputusan is berpengaruh) }\end{array}$ \\
{$[\mathrm{R} 7]$} & $\begin{array}{l}\text { If (frekuensi is tidak sering) and (aktifitas is sering } \\
\text { sekali) then (keputusan is berpengaruh) }\end{array}$ \\
{$[\mathrm{R} 8]$} & $\begin{array}{l}\text { If (frekuensi is sering sekali) and (aktifitas is sering } \\
\text { sekali) then (keputusan is sangat berpengaruh) }\end{array}$ \\
{$[\mathrm{R} 9]$} & $\begin{array}{l}\text { If (frekuensi is sering) and (aktifitas is sering) then } \\
\text { (keputusan is berpengaruh) }\end{array}$ \\
&
\end{tabular}

\subsection{Hasil}

Hasil dari perancangan fuzzy logic ini dapat dilihat

(7) apabila aplikasi ini dijalankan pada sebuah computer Himpunan fuzzy berpengaruh memiliki domain [2,5,8] dengan aplikasi Visual basic. Pengguna sistem fuzzy dengan derajat keanggotaan tertingginya $(=1)$ terletak logic ini dapat melakukan pengisian kuesioner pada pada nilai 5. Himpunan fuzzy berpengaruh form yang sudah disedikan. Pengguna dapat memilih direpesentasikan dengan fungsi keanggotaan berbentuk beberapa menu form dan ditampilkan pada form utama segitiga, seperti terlihat pada persamaan 8 . yang terdapat dalam aplikasi. Untuk lebih jelasnya dapat dilihat pada Gambar 7. 


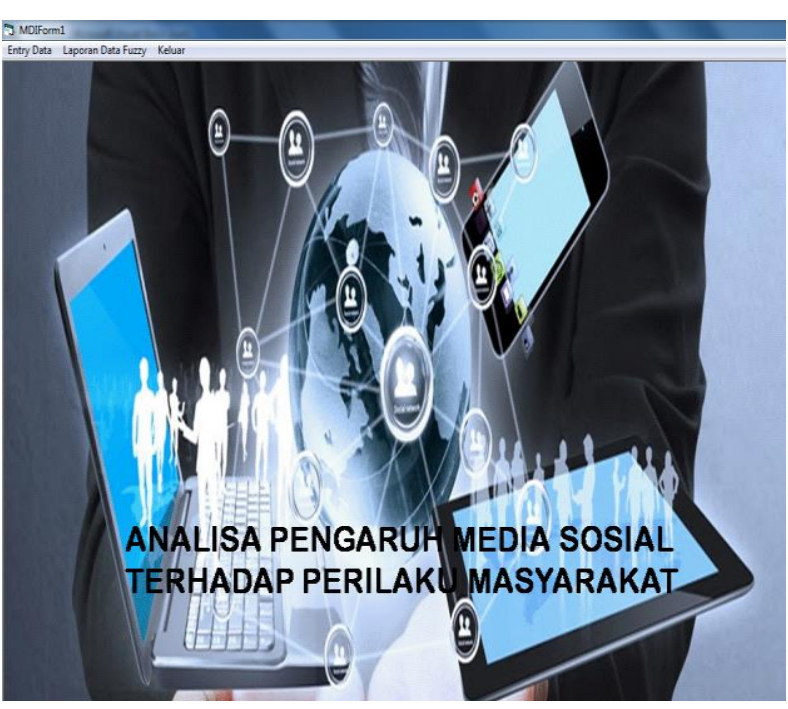

Gambar 7. Tampilan Menu Utama

Pada form ini terdapat halam untuk mengentrikan data responden seperti gambar 8 .

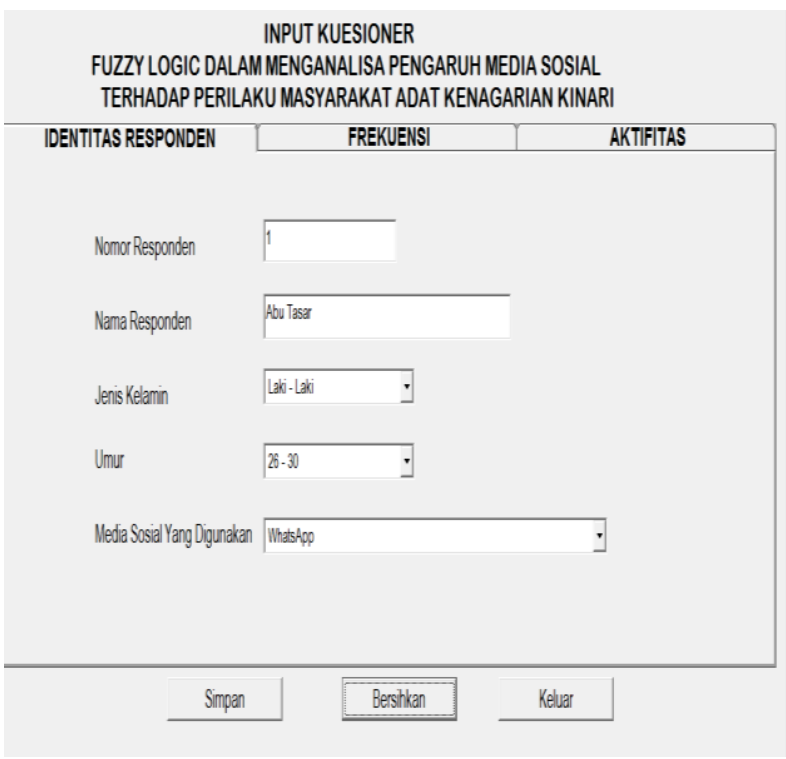

Gambar 8. Identitas Responder

Pada form ini terdapat halam untuk mengentrikan Variabel Frekuensi seperti gambar 9.

Pada form ini terdapat halam untuk mengentrikan Variabel Aktifitas seperti gambar 10.

Pada form ini merupakan proses pemanggilan data kuesioner yang sudah diinputkan sebelumnya, selanjutnya untuk dilakukan pemrosesan fuzzy sehingga memperoleh kesimpulan terhadap pengaruh media sosial terhadap masyarakat, seperti gambar 11 .

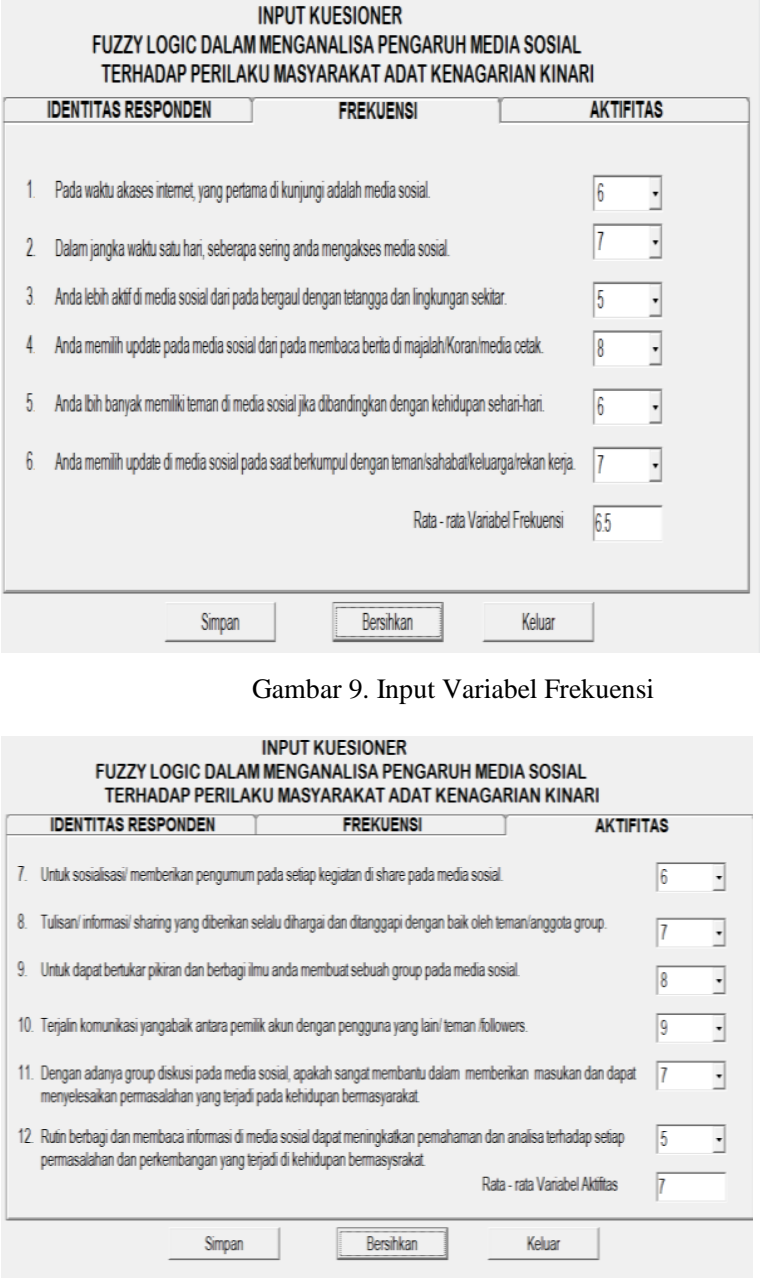

Gambar 10. Input Variabel Frekuensi

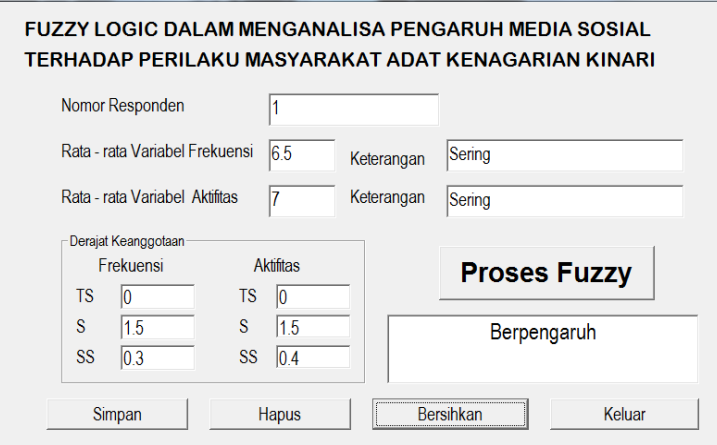

Gambar 11. Tampilan Pemrosesan Fuzzy

Hasil Kuesioner Fuzzy Logic yang diisi oleh masyarakat dapat dilihat pada Tabel 2.

Pada Penelitian ini ujicoba dilakukan pada 20 orang masyarakat, dimana pada hasil kuesioner tersebut dan dibandingkan dengan hasil konsultasi bersama tokoh masyarakat maka diperoleh keakuratan dari sistem ini sebesar $85 \%$. 
Irzal Arief Wisky, Dhio Saputra

Jurnal RESTI (Rekayasa Sistem dan Teknologi Informasi) Vol . 2 No. 3 (2018) 639 - 645

Tabel 2 : Hasil Kuisioner

\begin{tabular}{|c|c|c|c|c|c|c|c|c|c|c|c|c|c|}
\hline \multirow[t]{2}{*}{ No } & \multirow{2}{*}{$\begin{array}{c}\text { Nama } \\
\text { Respo } \\
\text { nden }\end{array}$} & \multirow{2}{*}{$\begin{array}{c}\text { Media } \\
\text { Sosial } \\
\text { Yang } \\
\text { Digun } \\
\text { akan }\end{array}$} & \multicolumn{6}{|c|}{ Frekuensi } & \multicolumn{5}{|c|}{ Aktifitas } \\
\hline & & & 1 & 2 & 3 & 4 & 5 & 6 & 7 & 8 & 9 & $\begin{array}{l}1 \\
0\end{array}$ & $\begin{array}{l}1 \\
1\end{array}$ \\
\hline 1 & $\begin{array}{l}\text { NAM } \\
\text { A KK }\end{array}$ & $\begin{array}{l}\text { Whats } \\
\text { App }\end{array}$ & 6 & 7 & 5 & 8 & 6 & 7 & 6 & 7 & 8 & 9 & 7 \\
\hline 2 & $\begin{array}{l}\text { AFRI } \\
\text { ZAL }\end{array}$ & $\begin{array}{l}\text { Faceb } \\
\text { ook }\end{array}$ & 6 & 5 & 7 & 8 & 7 & 6 & 5 & 6 & 7 & 6 & 6 \\
\hline 3 & $\begin{array}{l}\text { ARM } \\
\text { A } \\
\text { EDIS } \\
\text { ON }\end{array}$ & $\begin{array}{l}\text { Faceb } \\
\text { ook }\end{array}$ & 7 & 6 & 7 & 6 & 6 & 7 & 6 & 7 & 6 & 7 & 5 \\
\hline 4 & $\begin{array}{l}\text { ARMI } \\
\text { S }\end{array}$ & $\begin{array}{l}\text { Faceb } \\
\text { ook }\end{array}$ & 4 & 3 & 3 & 3 & 3 & 3 & 2 & 3 & 2 & 3 & 3 \\
\hline 5 & $\begin{array}{l}\text { BUDI } \\
\text { DESP } \\
\text { IAN }\end{array}$ & $\begin{array}{l}\text { Whats } \\
\text { App }\end{array}$ & 7 & 8 & 7 & 6 & 8 & 7 & 6 & 9 & 8 & 6 & 6 \\
\hline 6 & $\begin{array}{l}\text { DALI } \\
\text { ANA }\end{array}$ & $\begin{array}{l}\text { Whats } \\
\text { App }\end{array}$ & 6 & 4 & 7 & 7 & 7 & 6 & 5 & 8 & 7 & 7 & 7 \\
\hline 7 & $\begin{array}{l}\text { NURS } \\
\text { AL }\end{array}$ & $\begin{array}{l}\text { Whats } \\
\text { App }\end{array}$ & 5 & 5 & 5 & 7 & 6 & 5 & 6 & 7 & 6 & 7 & 6 \\
\hline 8 & $\begin{array}{l}\text { PURN } \\
\text { OMO }\end{array}$ & $\begin{array}{l}\text { Instag } \\
\text { ram }\end{array}$ & 6 & 6 & 6 & 6 & 5 & 6 & 7 & 6 & 5 & 8 & 5 \\
\hline 9 & $\begin{array}{l}\text { SAHR } \\
\text { IAL }\end{array}$ & $\begin{array}{l}\text { Instag } \\
\text { ram }\end{array}$ & 7 & 5 & 5 & 7 & 5 & 7 & 7 & 6 & 6 & 7 & 6 \\
\hline 10 & $\begin{array}{l}\text { SAHR } \\
\text { IAL }\end{array}$ & $\begin{array}{l}\text { Whats } \\
\text { App }\end{array}$ & 8 & 4 & 6 & 6 & 6 & 7 & 6 & 7 & 7 & 6 & 7 \\
\hline 11 & $\begin{array}{l}\text { SARI } \\
\text { MAN }\end{array}$ & $\begin{array}{l}\text { Whats } \\
\text { App }\end{array}$ & 7 & 7 & 6 & 6 & 7 & 6 & 5 & 8 & 6 & 7 & 6 \\
\hline 12 & $\begin{array}{l}\text { SANT } \\
\text { OSO }\end{array}$ & $\begin{array}{l}\text { Whats } \\
\text { App }\end{array}$ & 9 & 8 & 5 & 7 & 8 & 6 & 6 & 7 & 5 & 6 & 5 \\
\hline 13 & $\begin{array}{l}\text { SUAR } \\
\text { IDI }\end{array}$ & $\begin{array}{l}\text { Whats } \\
\text { App }\end{array}$ & 7 & 7 & 7 & 8 & 9 & 5 & 5 & 6 & 4 & 5 & 6 \\
\hline 14 & $\begin{array}{l}\text { SUH } \\
\text { ATRI }\end{array}$ & $\begin{array}{l}\text { Faceb } \\
\text { ook }\end{array}$ & 3 & 3 & 3 & 3 & 3 & 4 & 3 & 2 & 3 & 3 & 3 \\
\hline 15 & $\begin{array}{l}\text { SULA } \\
\text { IMAN }\end{array}$ & $\begin{array}{l}\text { Faceb } \\
\text { ook }\end{array}$ & 7 & 9 & 5 & 6 & 7 & 6 & 5 & 8 & 6 & 7 & 6 \\
\hline 16 & $\begin{array}{l}\text { SUM } \\
\text { ARDI }\end{array}$ & $\begin{array}{l}\text { Faceb } \\
\text { ook }\end{array}$ & 5 & 8 & 7 & 5 & 7 & 6 & 7 & 7 & 7 & 6 & 5 \\
\hline 17 & $\begin{array}{l}\text { RISM } \\
\text { AN }\end{array}$ & $\begin{array}{l}\text { Faceb } \\
\text { ook }\end{array}$ & 7 & 7 & 6 & 6 & 6 & 5 & 6 & 6 & 6 & 5 & 6 \\
\hline 18 & $\begin{array}{l}\text { RUSL } \\
\text { I }\end{array}$ & $\begin{array}{l}\text { Faceb } \\
\text { ook }\end{array}$ & 4 & 3 & 3 & 3 & 3 & 3 & 2 & 2 & 3 & 3 & 3 \\
\hline 19 & $\begin{array}{l}\text { SYAF } \\
\text { RIAN } \\
\text { TO }\end{array}$ & $\begin{array}{l}\text { Whats } \\
\text { App }\end{array}$ & 6 & 6 & 5 & 7 & 6 & 7 & 6 & 8 & 5 & 7 & 6 \\
\hline 20 & $\begin{array}{l}\text { SYAF } \\
\text { RIZA } \\
\text { L } \\
\end{array}$ & $\begin{array}{l}\text { Whats } \\
\text { App }\end{array}$ & 7 & 8 & 6 & 7 & 6 & 8 & 5 & 8 & 6 & 8 & 5 \\
\hline
\end{tabular}

Kesimpulan hasil Fuzzy Logic :

Fuzzy logic memperoleh hasil bahwa pengaruh media sosial terhadap masyarakat dengan tingkat kepastian 85 $\%$.

\section{Kesimpulan}

\subsection{Simpulan}

Sudah dibangun sebuah aplikasi sistem informasi fuzzy logic untuk menganalisa pengaruh media sosial terhadap perilaku masyarakat, sehingga membantu masyarakat mengenali variabel-variabel penyebab utama pengaruh media sosial, serta dengan adanya aplikasi sistem informasi ini dapat dijadikan solusi alternatif bagi masyarakat untuk melakukan diagnose ${ }_{1}^{1}$ dini terhadap variabel-variabel pengaruh media sosial. ${ }_{5}^{2}$ Sistem ini mampu menyimpan representasi ${ }^{5}$ pengetahuan berdasarkan nilai Himpunan Fuzzy dengan ${ }_{6}^{6}$ keakuratan sebesar $85 \%$.

5.2 Saran

Berpengaruh

${ }^{3}$ Untukidak beneng $_{\text {bution }}$ selitianjutnya dengan menggunakan ${ }^{6}$ metode fuzzy logic model tahani, pengujian sebaiknya dengangmenggunakan dua model, sehingga pemrosesan ${ }^{5}$ data dapat dilakukan lebih baik dan menghasilkan 4output yang tepat, sehingga dalam tahapan ${ }_{5}$ periegangiroilan keputusan menghasilkan keputusan yang efekctifindan tepat.

Berpengaruh

${ }^{5}$ Daftar Rujukan

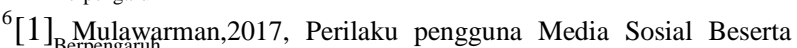
Implikasinya Ditinjau dari Perspektif Psikologi Sosial Terapan, BBpdetinuPsikologi, ISSN : 2528-5858. Vol 25, No.1.

${ }^{6}$ [2] Nasrullah, R. (2015). Media Sosial (Perspektif Komunikasi, Berpedgaruh,

[3] Bæbidigastuti Nelly Indian,2012, Model Perilaku Perjalanan Agenagen Menggunakan Fuzzy Logic, Jurnal komputer dan Berpengramulika, SSN : 2249-9551 Edisi I vol 1.

[4] Berpughaul, D. (2007). Themes in media theory. New York : Open University Press.

${ }_{3}$ [5] ${ }^{\text {Berpentaqnuh }}$ C. (2014). Social Media Critical introduction. Los BAptidak

76] Surya Candra., 2018.Jurnal Resti : Penilaian Kinerja Dosen Menggunakan Metode Topsis, 2 (1), pp.322-329.

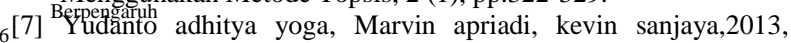
Optimalisasi Lampu Lalu Lintas dengan Fuzzy Logic, Jurnal

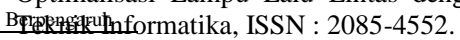

[8] Rohayani Hetti,2013, Analisis sistem pendukung keputusan dalam memilih program studi dengan menggunakan metode logika fuzzy, Jurnal sistem Informasi (JSI), ISSN : 20851588. Vol 5, No.1.

[9] Kusumadewi, Sri dan Hari Purnomo. 2010. Aplikasi Logika Fuzzy Logic Untuk Mendukung Keputusan, Yogyakarta : Graha Ilmu.

[10] Robby, Kwanentent, \& Wardana, 2009, Fzzy Logic, Andi Offset, Yogyakarta.

[11] Wati Prasetyo, 2007, Kecerdasan Buatan, Andi Offset, Yogyakarta.

[12] Sutanta, E., 2003. Sistem Informasi Manajemen. 1 st ed. Yogyakarta : Graha Ilmu. 